\title{
IMPLIKASI YURIDIS PERATURAN PEMERINTAH TENTANG PUNGUTAN OTORITAS JASA KEUANGAN TERHADAP NOTARIS PEMEGANG SURAT TANDA TERDAFTAR YANG TIDAK PERNAH BERKEGIATAN DI PASAR MODAL
}

\author{
Ratna Ayu Puspitasari, Imam Koeswahyono, Titik Soeryati Soekesi \\ Program Studi Magister Kenotariatan Fakultas Hukum Universitas Brawijaya \\ Jl. MT. Haryono, Nomor 169. Malang \\ E-mail: ratnaayu0701@gmail.com
}

\begin{abstract}
Financial Services Authority (OJK) in conducting supervision and regulation of the financial services sector, and the juridical implications of Government Regulation Number 11 of 2014 concerning OJK Levy for capital market notaries registered with Registered Letters (STTD) who are not active in the capital market. The research method used in this paper is a normative juridical. The results of the study indicate that the OJK has the authority to levy notaries. Legal implications arising from Government Regulation Number 11 of 2014 concerning Financial Services Authority Levies for notaries who have STTD but do not engage in capital market activities becomes the state's receivables. Payments will be made by the state receivable committee, with a forced letter that has the same legal force as the Grosse deed.
\end{abstract}

Keywords: capital market notary, financial services authority levy, registered letter

\begin{abstract}
Abstrak: tulisan ini bertujuan untuk mendeskripsikan kewenangan Otoritas Jasa Keuangan (OJK) dalam melakukan pengawasan dan pengaturan sektor jasa keuangan, dan implikasi yuridis Peraturan Pemerintah Nomor 11 Tahun 2014 tentang Pungutan OJK terhadap notaris pasar modal pemegang Surat Tanda Terdaftar (STTD) yang tidak berkegiatan di pasar modal. Metode penelitian yang digunakan dalam penulisan ini adalah yuridis normatif dengan pendekatan perundang-undangan. Hasil kajian menunjukkan bahwa OJK memiliki kewenangan untuk melakukan pungutan terhadap notaris. Implikasi hukum yang timbul dari Peraturan Pemerintah Nomor 11 Tahun 2014 tentang Pungutan Otoritas Jasa Keuangan bagi notaris yang memiliki STTD namun tidak berkegiatan di pasar modal adalah menjadi piutang negara. Pembayaran akan dilakukan oleh panitia urusan piutang negara, dengan surat paksa yang mempunyai kekuatan hukum yang sama dengan grosse akta.
\end{abstract}

Kata Kunci: notaris pasar modal, pungutan otoritas jasa keuangan, surat tanda terdaftar

\section{PENDAHULUAN}

Perseroan publik dapat menciptakan iklim investasi posititf dalam memajukan pembangunan ekonomi di Indonesia, melalui pasar modal. Dalam kegiatannya pasar modal membutuhkan suatu lembaga dan profesi penunjang agar pelaksaan kegiatan pasar modal dapat dilaksanakan. UndangUndang Pasar Modal dalam Pasal 64 ayat (1) menyatakan bahwa profesi penunjang pasar modal terdiri dari akuntan, konsultan hukum, notaris, penilai, dan profesi lain yang ditetapkan oleh peraturan pemerintah ialah Bapepam.

Badan Pengawas Pasar Modal dan Lembaga Keuangan (Bapepam-LK) adalah lembaga yang memiliki tugas pengaturan, pembinaan dan pengawasan pasar modal. Namun sejak tanggal 31 Desember 2012 
Bapepam-LK digantikan menjadi bagian dari Otoritas Jasa Keuangan (OJK) (Balfas, 2012:8). Hal ini juga berlaku bagi pengaturan dan pengawasan jasa keuangan di perbankan yang sebelumnya berada di bawah Bank Indonesia (BI) menjadi beralih pada OJK sejak 31 Desember 2013.

Sehingga Indonesia menerapkan konsep pengawasan terintegrasi terhadap seluruh jasa keuangan dengan menyatu ke dalam OJK. Pada Undang-Undang Otoritas Jasa Keuangan pasal 6 huruf c menyebutkan, " $O J K$ mempunyai tugas melaksanakan pengaturan dan pengawasan pada jasa keuangan di bidang pasar modal". Kemudian, dalam Pasal 9 huruf c dijelaskan bahwa terkait tugas OJK seperti yang tercantum dalam Pasal 6 tersebut, wewenang OJK, melakukan pemeriksaan, pengawasan penyidikan, perlindungan konsumen, dan tindakan lain terhadap lembaga jasa keuangan, pelaku, dan atau penunjang jasa keuangan.

Lahirnya Peraturan Pemerintah Nomor 11 Tahun 2014 tentang Pungutan Otoritas Jasa Keuangan, Lembaran Negara Republik Indonesia Tahun 2014 Nomor 33, lalu, Tambahan Lembaran Negara Republik Indonesia Nomor 5504 (selanjutnya disingkat PP tentang Pungutan OJK), justru menjadi polemik. Pada pasal 5 PP tenang Pungutan OJK itu menjelaskan, dalam rangka pengawasan, pengaturan, pemeriksaan oleh OJK, maka OJK berhak melakukan pungutan.

Pungutan tersebut diharapkan dapat menjadi pemasukan bagi OJK sehingga pada masa mendatang tidak lagi bergantung pada Anggaran Pendapatan dan Belanja Negara (APBN). Pungutan tersebut berdasarkan pada amanat Pasal 37 Undang-Undang Otoritas Jasa Keuangan (UU OJK), memberikan kewenangan OJK untuk melakukan pungutan terhadap sektor keuangan dan pihak-pihak yang melakukan kegiatan di sektor jasa keuangan wajib membayar pungutan kepada OJK. Salah satu imbas terhadap pungutan tersebut adalah notaris sebagai profesi penunjang pasar modal.

Notaris merupakan pejabat umum.
Hal ini telah diatur dalam Undang-Undang Nomor 2 tahun 2014 tentang Perubahan Atas Undang-Undang Nomor 30 Tahun 2004 tentang Jabatan Notaris, Lembaran Negara Republik Indonesia Tahun 2014 Nomor 3, dan Tambahan Lembaran Negara Republik Indonesia Nomor 5491 (selanjutnya disebut UU Jabatan Notaris), bahwa peran notaris sebagaimana diatur merupakan pejabat umum yang membuat maupun mengesahkan akta otentik dan memiliki kewenangan lainnya selama itu diperintahkan oleh undang-undang. Hal ini bermakna bahwa jika akta otentik itu diperintahkan oleh undang-undang untuk dibuat oleh notaris, maka harus dibuat oleh atau dihadapan notaris, bukan oleh pejabat umum lainnya. Namun jika undang-undang memerintahkan pembuat akta otentik dibuat oleh pejabat umum lainnya, barulah notaris tidak berhak untuk membuatnya.

Peran notaris yang paling umum adalah sebagai Pejabat Pembuat Akta Tanah (PPAT) sebagaimana telah diatur UU Nomor 30 tahun 2004 Tentang Jabatan Notaris serta Undang-Undang Jabatan Notaris salah satunya adalah pemisahan harta waris dilaksanakan dalam suatu akta di muka seorang Notaris (Pasal 1074, KUHPer) (Pramarta dkk, 2019:23). Sesuai dengan amanat UndangUndang Nomor 24 Tahun 2013 Tentang Administrasi Kependudukan Kewenangan notaris mengenai pembuatan surat keterangan waris dapat dilakukan dengan mengajukan permohonan ke Kantor Pertanahan setempat yang biasanya bekerjasama dengan notaris (Yoga dkk, 2018:134).

Melihat pentingnya peran notaris yang juga sebagai profesi penunjang pasar modal, tidak bisa hanya dipandang sebagai profesi. Tetapi juga sebagai pejabat yang telah disebutkan dalam undang-undang. Ketika OJK mengeluarkan peraturan terkait pungutan OJK yang mempunyai dampak terhadap notaris, Ikatan Notaris Indonesia (INI) sebagai organisasi tertinggi yang menaungi notaris tidak dilibatkan dalam pembuatan peraturan pemerintah tersebut. Penolakan terhadap pungutan OJK tersebut 
tidak hanya dilakukan oleh notaris tetapi juga beberapa profesi penunjang lainnya dalam pasar modal terkait pungutan OJK tersebut.

Notaris melalui INI telah mengajukan yudisial review terhadap penolakan pungutan tersebut kepada Mahkamah Agung. Namun ada tanggal 22 Januari 2015 diputuskan tidak dapat diterima oleh Mahkamah Agung, atau Niet Ontvankelijke Verklaard dengan nomor registrasi 68P/HUM/2014. Sehingga pungutan tersebut tetap berlaku sampai sekarang.

Pendaftaran notaris sebagai profesi pasar modal yang ditandai dengan STTD, akan tetapi memiliki STTD tidak memberikan jaminan seorang notaris pernah berkegiatan di pasar modal atau membuat akta terkait pasar modal. Pungutan menjadi tidak adil jika hanya melihat semua notaris pasar modal. Pungutan terhadap notaris yang berkegiatan di pasar modal juga tidak tepat jika dilakukan pada saat kewenangan pengawasan beralih pada OJK. Sebelum pengawasan dan pengaturan notaris sebagai profesi penunjang di pasar modal dilakukan oleh OJK, Bapepam yang menjadi lembaga pengawas notaris pasar modal tidak pernah melakukan pungutan.

Pungutan tahunan, sebagaimana diatur OJK kepada notaris, tidak mencerminkan keadilan jika harus diterapkan kepada semua notaris pemegang STTD dikarena tidak semua notaris pemegang STTD membuat akta terkait pasar modal. Pungutan tahunan sebesar Rp 5.000.000,- (lima juta rupiah) yang harus dibayar setiap tahun menjadi tidak adil jika harus dibayar oleh notaris pemegang STTD namun belum pernah membuat akta.

Berdasarkan uraian di atas, permasalahan yang diangkat dalam penulisan ini adalah (1) kewenangan Otoritas Jasa Keuangan (OJK) dalam melakukan pengawasan dan pengaturan sektor jasa keuangan, dan (2) implikasi yuridi dalam Pasal 5 Peraturan Pemerintah Nomor 11 Tahun $2 \mathrm{Ol} 4$ tentang Pungutan Otoritas Jasa Keuangan terhadap notaris pasar modal pemegang STTD yang tidak pernah berkegiatan dipasar modal dan tidak membayar pungutan sebagaimana diatur.

\section{METODE}

Metode yang digunakan dalam penulisan artikel ini adalah yuridis normatif (normative legal research). Pendekatan yang digunakan dalam penelitian ini adalah pendekatan perundang-undangan (statute approach). Pendekatan perundang-undangan digunakan karena isu hukum yang diteliti merupakan konflik norma dalam perundang-undangan, antara UU OJK dengan PP Pungutan OJK, sehingga pendekatan perundangundangan merupakan pendekatan yang tepat. Pendekatan perundang-undangan tidak saja melihat bentuk undang-undang, tetapi juga memahami materi muatan dalam peraturan tersebut, yaitu UU Otoritas Jasa Keuangan yang memiliki tugas fungsi pengawasan terhadap pihak yang berkegiatan di jasa keuangan, yang tidak menyebutkan notaris, PP Pungutan OJK. Karena PP merupakan peraturan pelaksana, namun dalam PP Pungutan OJK terjadi perluasan makna pengawasan yang tidak sesuai dengan UU OJK dengan adanya pungutan.

Bahan hukum yang digunakan dalam penulisan ini adalah dengan bahan hukum primer yang berupa peraturan perundangundangan, bahan hukum sekunder yang terdiri dari buku teks, jurnal hukum, bahan hukum tersier yaitu bahan hukum yang memberikan petunjuk maupun penjelasan tentang bahan hukum primer dan bahan hukum sekunder, seperti kamus istilah hukum. Setelah bahan hukum primer diperoleh maupun bahan penunjang lainnya diperoleh, selanjutnya dilakukan seleksi untuk disusun dan dianalisis secara kualitatif. Bahan hukum tersebut kemudian diterjemahkan dengan logis dan sistematis.

Penyelesaian konflik norma yang berkaitan dengan asas preferensi hukum. Isu hukum yang diteliti diterjemahkan melalui reinterprestasi dengan mengikuti asas-asas 
preferensi, dan menginterprestasi pada norma yang utama. Kemudian menginterprestasi norma preferensi serta menerapkannya dengan mengesampingkan norma yang lain (Hadjon dan Djatmiati, 2011:31-32).

Reinterpretasi mengenai pengawasan dan pengaturan yang menjadi tugas OJK, bahwa, pertama tugas pokok OJK adalah melakukan pengawasan dan pengaturan. Arti pengawasan dan pengaturan inilah yang membuat OJK dapat melakukan pungutan, sedangkan dalam naskah akademik rancangan UU OJK tidak menyebutkan bahwa fungsi OJK dapat melakukan pungutan, oleh karena itu perlu penelusuran dalam risalah sidang dalam pembahasan UU OJK lebih mendetail.

Kedua, penggunaan asas lex superior derogat lex inferior, apabila terdapat konflik hukum antara peraturan perundang-undangan yang lebih rendah tingkatannya, maka peraturan perundang-undangan yang lebih rendah dikesampingkan dalam hal ini UU OJK dengan PP Pungutan OJK maka yang harus dikesampingkan adalah PP Pungutan OJK. Kemudian dilakukan analisa masalah yang diteliti dengan cara memaparkan bahan hukum yang telah diperoleh dari studi pustaka dan undang-undang dianalisis dalam bentuk kesimpulan.

\section{HASIL DAN PEMBAHASAN}

\section{Kewenangan Otoritas Jasa Keuangan} (OJK) dalam Melakukan Pengawasan dan Pengaturan Sektor Jasa Keuangan

Implikasi merupakan dampak atau akibat dari adanya suatu kebijakan yang dapat bersifat baik maupun buruk. Kebijakan tesebut harus berdasarkan pada kewenangan yang sah secara hukum. Kekuasaan dan kewenangan merupakan hal yang berbeda dalam hukum. Pengalihan kewenangan Bapepam-LK kepada OJK terjadi sejak tanggal 31 Desember 2012. Maka tugas, fungsi, pengawasan dan pengaturan Bapepam-LK beralih pada OJK. Beralihnya kewenangan tersebut mengakibatkan kekayaan dan pegawai juga beralih pada OJK untuk menunjang kerja. Pengalihan kewenangan BapepamLK dan BI kepada OJK merupakan amanah dari Undang-Undang Bank Indonesia yang menghendaki adanya pengawasan yang terintegasi di bawah satu atap oleh OJK. Setidaknya ada tiga hal yang melatarbelakangi terbentunya OJK, yaitu perkembangan industri sektor jasa keuangan di Indonesia, permasalahan lintas sektoral industri jasa keuangan serta amanat Undang-Undang Bank Indonesia yang merupakan respon dari krisis 1998 yang berdampak sangat besar terhadap Indonesia, khususnya sektor jasa perbankan.

Krisis tahun 1997-1998 yang melanda Indonesia menyebabkan banyak bank di Indonesia yang terpuruk dan terpaksa di tutup, sehingga saat itu kinerja BI dipertanyakan sebagai lembaga pengawas. Reformasi hukum di bidang keuangan diharapkan dapat membantu atau memperbaiki krisis 1998 sehingga tercipta suatu sistem keuangan yang tangguh. Untuk itu terbetuklah ide awal untuk membentuk OJK yang sebenarnya adalah hasil kompromi untuk menghindari jalan buntu pembahasan undang-undang tetang Bank Indonesia oleh Dewan Perwakilan Rakyat. Sehingga permasalahan yang muncul adalah dengan membentuk lembaga pengawas di sektor perbankan di luar BI maka terlihat seperti memangkas kewenangan BI sebagai bank sentral untuk melakukan pengawasan. Oleh karena itu agar tidak terlihat memangkas kewenangan BI maka lembaga pengawas yang akan dibentuk juga harus mengawasi sektor jasa keuangan lainnya.

Lembaga pengawas yang sebelumnya diamanatkan hanya terkait pengawasan dalam perbankan juga melakukan pengawasan terhadap lembaga jasa keuangan lainnya, oleh karena itu lembaga pengawas tersebut dalam perkembangannya berubah nama menjadi Otoritas Jasa Keuangan (OJK). OJK secara filosofi dibentuk dengan tujuan agar keseluruhan kegiatan jasa keuangan didalam 
sektor jasa keuangan dapat terselenggara secara teratur, transparan, adil, dan akuntabel. OJK diharapkan dapat mewujudkan sistem keuangan yang tumbuh secara berkelanjutan dan stabil. Dibentuk dan dilandaskan pada prinsip-prinsip tata kelola yang baik, seperti independen, akuntabilitas, pertanggung jawaban, transparansi dan kewajaran (fairness). Sehingga OJK dalam hal ini diharapkan dapat mendukung kepentingan sektor jasa keuangan skala nasional. Mampu meningkatkan daya saing nasional. Selain itu, OJK diharapkan mampu untuk melindungi kepentingan nasional, seperti sumber daya manusia, pengelolan, pengendalian, dan kepentingan di sektor jasa keuangan. OJK juga diharapkan mampu melindungi kepentingan konsumen dan masyarakat, termasuk perlindungan terhadap penyelenggara dan kejahatan di sektor keuangan seperti manipulasi dan berbagai bentuk penggelapan dalam kegiatan di sektor jasa keuangan.

OJK yang mendapatkan kewenangan atribusi yang berasal dari UU Bank Indonesia dan Undang-Undang Otoritas Jasa Keuangan, untuk melaksanakan tugas pengawasan dan pengaturan dalam sektor jasa keuangan. Kewenangan OJK dalam melakukan pengawasan maupun pengaturan haruslah didasarkan pada masing-masing undang-undang atau bertumpuh pada undang-undang yang lebih sektoral atau spesifik. Jika pengawasan OJK terhadap pasar modal maka harus mengacuh pada Undang-Undang Pasar Modal. Hal ini untuk mewujudkan efektifitas dari pengawasan tersebut. Sebagaimana disebutkan dalam Undang-Undang Pasar Modal bahwa pengaturan dan pengawasan haruslah mewujudkan terciptanya kegiatan Pasar Modal yang teratur, wajar, dan efisien serta melindungi kepentingan pemodal dan masyarakat.

Salah satu kebijakan pengawasan dan pengaturan OJK dalam pasar modal melalui kebijakan PP Pungutan OJK. PP pungutan OJK yang mewajibkan adanya pungutan yang harus dibayar oleh profesi penunjang pasar modal setiap tahunnya, tidak sesuai dengan Undang-Undang Pasar Modal maupun Undang-Undang Otoritas Jasa Keuangan itu sendiri. Undang-Undang Otorita Jasa Keuangan mengamanatkan bahwa pembentukan OJK bertujuan agar keseluruhan kegiatan dalam sektor jasa keuangan terselenggra secara teratur, adil, transparan, dan akuntabel, serta mewujudkan sistem keuangan yang berkelanjutan dan stabil. Tidak hanya itu OJK harus dapat melindungi kepentingan konsumen dan masyarakat.

Pengawasan dan pengaturan OJK dalam pasar modal harulah mengikuti atau menyesuaikan dengan Undang-Undang Pasar Modal. Mengingat Pasar Modal merupakan sumber pembiayaan dunia usaha dan sebagai wahana investasi bagi para pemodal yang memiliki peranan yang strategis untuk menunjang pelaksanaan pembangunan nasional, kegiatan pasar modal perlu mendapatkan pengawasan agar dapat dilaksanakan secara teratur, wajar, dan efisien. Pasal 4 Undang-Undang Pasar Modal menjelaskan bahwa badan pengawasan pasar modal oleh suatu badan pengawas dilakukan dengan pembinaan, pengaturan, dan pengawasan sebagaimana dimaksud dalam Pasal 3 Undang-Undang Pasar Modal dilaksanakan oleh Bapepam (sekarang beralih kepada OJK) dengan tujuan mewujudkan terciptanya kegiatan pasar modal yang teratur, wajar, dan efisien serta melindungi kepentingan pemodal dan masyarakat.

Pasar modal yang mempunyai peran penting terkait perekonomian suatu negara dalam kegiatannya membutuhkan lembaga dan profesi menunjang untuk membantu pelaksanaan pasar modal. Pasal 64 ayat (1) Undang-Undang Pasar Modal menyatakan bahwa notaris, akuntan, konsultan hukum dan profesi lain yang ditetapkan dengan peraturan adalah profesi yang menunjang pasar modal. Undang-Undang Pasar Modal 
memberikan amanat bahwa dalam melakukan kegiatan pasar modal memerlukan sebuah badan pengawas. Badan pengawas dalam hal ini mempunyai peran dan kewenangan terkait penegakan dan pelaksanaan ketentuan yang ada dalam Undang-Undang Pasar Modal agar semua pihak terlindungi kepentingan pemodal dan masyarakat. Sehingga kegiatan yang terjadi dalam pasar modal menjadi teratur, wajar, dan efisien.

Pasal 6 huruf c Undang-Undang Otoritas Jasa Keuangan, menyebutkan bahwa OJK mempunyai tugas melaksanakan pengaturan dan pengawasan pada jasa keuangan di bidang pasar modal. Kemudian, dalam Pasal 9 huruf c dijelaskan bahwa terkait tugas OJK seperti yang tercantum dalam Pasal 6 tersebut, wewenang OJK, melakukan pemeriksaan, pengawasan penyidikan, perlindungan konsumen, dan tindakan lain terhadap lembaga jasa keuangan, pelaku, dan atau penunjang jasa keuangan.

Praktik pungutan OJK bertujuan agar pembiayaan kegiatan OJK terkait pengawasan dan pengaturan sektor jasa keuangan didanai secara mandiri, yang pendanaannya bersumber dari pungutan kepada pihak yang melakukan kegiatan di sektor jasa keuangan. Dengan tujuan agar mendukung operasional OJK sehingga mampu melaksanakan tugas dan fungsinya secara independent dan profesional.

Jika melihat risalah sidang Rancangan Undang-Undang Otoritas Jasa Keuangan (selanjutnya disebut RUU OJK) yang dilakukan di Komisi XI DPR dengan agenda penjelasan RUU OJK oleh pemerintah dalam hal ini Menteri Keuangan dan Menteri Hukum dan HAM serta mendengarkan pendapat dari fraksi-fraksi di DPR. Maka usulan awal pembiayaan OJK sepunuhnya berasal dari pungutan yang dilakukan OJK. Pembiayaan OJK sepenuhnya berasal dari pungutan OJK merupakan usulan dari pemerintah, yang saat itu diwakili oleh Menteri Keuangan Agus Marto W. pada tanggal 18 Agustus 2010. Pemerintah saat itu memberi penjelasan bahwa pembiayaan OJK berasal dari pungutan biaya yang dilakukan oleh OJK, dan jika pungutan tersebut tidak mampu mencukupi kebutuhan operasional OJK, maka pembiayaan baru akan diambil dari APBN. Fraksi Partai Golongan Karya, yang diwakili oleh Edion Betaubun berpendapat seharusnya pembiayaan OJK sepenuhnya berasal dari APBN sebagai wujud pelayanan publik dan tanggung jawab negara. Fraksi Partai Demokrat memiliki pendapat yang berbeda, yaitu tidak selamanya pembiayaan OJK ditanggung oleh APBN. Hasil rapat tersebut akhirnya memutuskan untuk pembiayaan OJK berasal dari APBN dan pungutan yang dilakukan oleh OJK sendiri.

Pada dasarnya anggaran OJK bersumber dari APBN untuk memenuhi seluruh kebutuhan OJK. Tetapi penggunaan anggaran untuk membiayai kegiatan pengaturan dan pengawasan OJK tetap memiliki standar yang wajar di sektor jasa keuangan, untuk mengurangi beban APBN karena pengawasan perbankan yang dilakukan oleh Bank Indonesia selama ini yang juga menggunakan anggaran di luar APBN. Hal inilah yang menjadi sejarah lahirnya Pasal 34 Undang-Undang Otoritas Jasa Keuangan bahwa sumber pembiayaan OJK berasal dari APBN dan pungutan yang dilakukan OJK.

Pengertian pungutan dalam PP Pungutan OJK, memberikan definsi bahwa pungutan yang berarti sejumlah uang yang wajib dibayar oleh pihak yang melakukan kegiatan di sektor jasa keuangan. Sehingga pihak yang melakukan kegiatan di sektor jasa keuangan wajib membayar sejumah uang kepada OJK. Pengenaan pungutan OJK merupakan amanat dari Pasal 37 UndangUndang Otoritas Jasa Keuangan, bahwa OJK mengenakan pungutan terhadap pihakpihak yang melakukan kegiatan di sektor jasa keuangan dan pihak-pihak tersebut wajib membayar pungutan kepada OJK. Lahirnya PP Pungutan OJK terhadap profesi penunjang pasar modal inilah yang akhirnya menjadi polemik. Pasal 5 menjelaskan bahwa 
dalam rangka pengawasan, pengaturan, pemeriksaan oleh OJK, maka OJK berhak untuk melakukan pungutan. Pungutan tersebut diharapkan dapat menjadi pemasukan bagi OJK sehingga pada masa mendatang tidak lagi bergantung pada APBN.

Notaris sebagai profesi penunjang pasar modal baru disebutkan dalam penjelasan Pasal 5 PP Pungutan OJK. Dalam hal ini dijelaskan bahwa notaris terkena pungutan karena pendaftaran notaris sebagai profesi penunjang. Jenis pungutan OJK sendiri ada 2 (dua), pungutan tahunan sebesar Rp 5.000.000,- (lima juta rupiah) dan pungutan berdasarkan nilai kontrak ebear 1,2\% (satu koma dua persen) pernilai kontrak dari kegiatan di sektor jasa keuangan.

Penyebutan notaris sebagai pihak yang terkena dampak pungutan oleh OJK pada bagian penjelasan Pasal 5, sedangkan dalam Pasal 5 dan Undang-Undang Otoritas Jasa Keuangan, tidak menyebutkan adanya notaris. Pungutan tahunan OJK wajib dibayarkan oleh semua notaris ber-STTD. Pungutan kedua adalah berdasarkan nilai kontrak yang dilakukan dalam kegiatan di sektor jasa keuangan. Kedua jenis pungutan ini dilakukan pada profesi-profesi penunjang jasa keuangan, seperti akuntan publik, penilai publik, konsultan hukum, dan notaris.

Pungutan inilah yang membuat beberapa profesi penunjang, seperti Himpunan Konsultan Hukum Pasar Modal (HKKPM), Institut Akuntan Publik Indonesia (IAPI), Ikatan Notaris Indonesia (INI), serta beberapa pengacara dan konsultan hukum melakukan penolakan, dengan mengajukan gugatan ke Mahkamah Agung. Beberapa profesi terebut bersama-sama mengajukan keberatan hak uji materiil pada Mahkamah Agung namun dalam putusan gugutan terkait PP Pungutan OJK tersebut diputuskan tidak dapat diterima karena undang-undang yang menjadi dasar gugatan uji materiil sedang diiuji di Mahkamah Konstitusi.

Pungutan yang dilakukan OJK didasarkan pada Pasal 37 Undang-Undang Otoritas
Jasa Keuangan, namun dalam UndangUndang OJK tidak menyebutkan adanya profesi penunjang pasar modal atau dalam hal ini spesifik pada notaris. OJK hanya berhak melakukan pungutan pada pihak yang melakukan kegiatan di sektor jasa keuangan. Hal ini dipertegas kembali bahwa rencana kerja dan anggaran OJK termasuk pungutan OJK haruslah dengan persetujuan DPR sebagaimana dengan bunyi Pasal 36 Undang-Undang OJK.

Pembuatan Peraturan Pemerintah tentang Pungutan OJK tidak mendapatkan persetujuan DPR. Pembuatan PP Pungutan OJK hanya didasarkan pada Pasal 37. Pasal 34 sampai 37 merupakan satu kesatuan yang tidak dapat dipisahkan terkait rencana kerja dan anggaran OJK dalam bab VII UndangUndang OJK. Hal inilah yang mendasari bahwa pembuatan PP OJK secara yuridis kurang tepat. Konflik norma yang terjadi disini adalah PP Pungutan OJK yang hanya didasarkan pada 1 pasal yaitu Pasal 37 tanpa melihat Pasal 34 hingga Pasal 37 Undang-Undang Otoritas Jasa Keuangan. Sehingga dalam hal ini Undang-Undang OJK yang seharusnya menjadi dasar dan acuan, sehingga PP Pungutan OJK terhadap notaris berSTTD maupun profesi penunjang pasar modal lainnya tidak harus dilakukan oleh OJK.

Pembentukan Undang-Undang Otoritas Jasa Keuangan adalah untuk melakukan penataan kembali struktur pengorganisasian dari lembaga-lembaga yang melakukan tugas pengawasan dan pengaturan di sektor jasa keuangan. Berdasarkan penjelasan umum Undang-Undang Otoritas Jasa Keuangan menyebutkan bahwa secara khusus menyebutkan, bahwa negara (melalui OJK) harus memberikan perhatian serius terhadap sektor jasa keuangan yang melakukan "fungsi intermediasi".

Fungsi intermediasi yang diselenggarakan oleh berbagai lembaga jasa keuangan dalam perkembangannya telah memberikan kontribusi yang cukup signifikan dalam 
penyediaan dana untuk pembiayaan pembangunan ekonomi nasional. Oleh karena itu, Negara senantiasa memberikan perhatian yang serius terhadap perkembangan kegiatan sektor jasa keuangan tersebut, dengan mengupayakan terbentuknya kerangka peraturan dan pengawasan sektor jasa keuangan yang terintegrasi dan komprehensif.

Penggunaan istilah "fungsi intermeditasi" jelas ditujukan untuk lembaga keuangan seperti sektor perbankan atau setor jasa keuangan lainnya, bukan ditujukan kepada profesi penunjang seperti profesi penunjang pasar modal notaris. Sehingga harus ada reintepretasi fungsi OJK sebagai lembaga pengawas dan pengaturan jasa keuangan, bahwa OJK hanya akan melakukan pengawasan secara umun yang mengacu pada undang-undang sektoral yang menjadi pengawasannya, seperti Undang-Undang Pasar Modal, Undang-Undang Asuransi, dan lain-lain.

\section{Implikasi Yuridis PP Nomor 11 Tahun 2014 Terhadap Notaris yang Memiliki Surat Tanda Terdaftar Pasar Modal yang Tidak Berkegiatan di Pasar Modal dan Tidak Membayar Pungutan Otoritas Jasa Keuangan}

Implikasi adalah suatu akibat yang terjadi atau ditimbulkan karena pelaksanaan kebijakan atau program tertentu bagi sasaran pelaksanaan program, berdampak baik maupun tidak baik. Kebijakan pengawasan dan pengaturan oleh OJK dengan melakukan pungutan terhadap notaris yang memiliki STTD namun tidak melakukan kegiatan di pasar modal tentu akan memiliki dampak. Begitupula notaris yang memiliki STTD namun tidak pernah berkegiatan dan tidak membayar pungutan OJK akan mendapatkan implikasi hukum atau akibat hukum.

Akibat hukum merupakan suatu akibat yang ditimbulkan karena hukum terkait suatu perbuatan yang dilakukan subjek hukum (Ahmad Ali, 2008:192) Akibat hukum merujuk pada suatu akibat dari perbuatan yang dilakukan, dengan mendapatkan suatu akibat yang diatur dalam hukum. Sedangkan perbuatan yang dilakukan adalah perbuatan yang sesuai dengan hukum yang berlaku. Dalam hal ini perbuatan akibat hukum yang dimaksud adalah tidak membayar pungutan yang telah ditetapkan oleh OJK. Pengawasan dan pengaturan yang dilakukan OJK haruslah dilakukan berasarkan pada peraturan sebagamana dimaksud dalam peraturan perundang-undangan di sektor jasa keuangan tersebut. Maka pengaturan dan pengawasan OJK terhadap notaris sebagai profesi penunjang pasar modal, yang menjadi alasan bagi OJK untuk melakukan pungutan sebagaimana dalam PP Pungutan OJK, haruslah dilakukan sesuai dengan Pasal 3 dan Pasal 4 Undang-Undang Pasar Modal.

Sesuai dengan tujuan pembinaan, pengaturan dan pengawasan yang menjadi amanat Pasal 4 Undang-Undang Pasar Modal adalah untuk mewujudkan terciptanya kegiatan pasar modal yang teratur, wajar dan efisien serta melindungi kepentingan pemodal dan masyarakat. Bahwa pemungutan OJK tidak mencerminkan perlindungan kepada pemodal dan masyarakat. Profesi penunjang pasar modal, sebagaimana diketahui merupakan subyek hukum pajak yang tunduk pada Undang-Undang Nomor 7 Tahun 1983 tentang Pajak Penghasilan sebagaimana telah beberapa kali dirubah, dengan perubahan terakhir yaitu UndangUndang Nomor 36 Tahun 2008 (selanjutnya disebut Undang-Undang Pajak Penghasilan). Dengan adanya, pungutan OJK seolah-olah terjadi "pajak tambahan" atau "double taxation", dimana setiap transaksi yang dilakukan di pasar modal, oleh Profesi Penunjang Pasar Modal selain dikenakan pajak, juga dikenakan "Pungutan OJK".

Adanya pajak tambahan berupa pungutan OJK akan menjadi beban kepada emiten atau perusahaan publik yang menggunakan jasa notaris karena akan ada penambahan biaya kepada emiten atau perusahaan publik sehingga "prinsip wajar dan efisien" seperti 
dalam Undang-Undang Pasar Modal tidak berlaku dalam PP Pungutan OJK. Oleh karenanya ketentuan mengenai pungutan ini juga bertentangan dengan Undang-Undang Pasar Modal karena tidak mempunyai asas kemanfaatan terhadap pelaku pasar modal, hanya bermanfaat untuk kepentingan OJK jika melihat dari sudut pandang pembiayaan operasional OJK karena pungutan OJK digunakan sebagai biaya operasional OJK. OJK bukanlah lembaga yang berwenang mengatur mengenai jasa profesi, seperti advokat, akuntan publik dan atau notaris, karena profesi penunjang pasar modal tersebut bukan pihak yang melakukan kegiatan jasa keuangan sebagaimana dimaksud dalam Pasal 6 huruf $\mathrm{b}$ Undang-Undang OJK. Kegiatan jasa profesi dari para profesi penunjang pasar modal telah diatur oleh undang-undang atau peraturan lain secara tersendiri atau terpisah yang mengatur mengenai masing-masing kelembagaan atau profesi tersebut.

Paragraf 6 Penjelasan Umum UndangUndang OJK menyatakan bahwa pada dasarnya tujuan pembentukan lembaga pengawas seperti OJK adalah untuk mengawasi sektor-sektor jasa keuangan yang mencakup perbankan, asuransi, dana pensiun, sekuritas, modal ventura, dan perusahaan pembiayaan, serta badan-badan lain yang menyelenggarakan pengelolaan dana masyarakat. Dengan kata lain, fungsi pengaturan, pengawasan, pemeriksaan, dan penelitian OJK adalah ditujukan kepada lembaga jasa keuangan, yang kegiatan usahanya menyelenggarakan pengelolaan dana masyarakat, sedangkan jasa profesi atau kegiatan yang dijalankan oleh profesi penunjang pasar modal yang salah satunya adalah notaris, tidak melakukan kegiatan usaha yang berkaitan dengan pengelolaan dana masyarakat.

Pendaftaran notaris sebagai profesi pasar modal yang ditandai dengan STTD, akan tetapi memiliki STTD tidak memberikan jaminan seorang notaris pernah berkegiatan di pasar modal atau membuat akta terkait pasar modal. Pungutan menjadi tidak adil jika hanya melihat semua notaris pasar modal. Pungutan terhadap notaris yang berkegiatan di pasar modal juga tidak tepat jika dilakukan pada saat kewenangan pengawasan beralih pada OJK. Sebelum pengawasan dan pengaturan notaris sebagai profesi penunjang di pasar modal dilakukan oleh OJK, Bapepam yang menjadi lembaga pengawas notaris pasar modal tidak pernah melakukan pungutan.

Pungutan tahunan, sebagaimana diatur OJK kepada notaris, tidak mencerminkan keadilan jika harus diterapkan kepada semua notaris pemegang STTD, dikarenakan tidak semua notaris pemegang STTD membuat akta terkait pasar modal. Pungutan tahunan sebesar Rp 5.000.000,- (lima juta rupiah) yang harus dibayar setiap tahun menjadi tidak adil jika harus dibayar oleh notaris pemegang STTD namun belum pernah membuat akta.

Notaris sebagai salah satu wajib bayar memiliki kewajiban biaya tahunan dimulai sejak notaris memperoleh perizinan, persetujuan, pendaftran dan pengesahan atau memperoleh STTD-nya. Maka dalam hal ini tagihan dimulai sejak notaris memperoleh STTD pada saat pengawasan dan pengaturan oleh Bapepam-LK sedangkan dalam pelaksanaan peraturan perundang-undangan tidak berlaku surut. Namun implikasi atau dampak tagihan tetap berjalan beserta dendanya kepada notaris ber-STTD dan menjadi piutang negara.

Semua notaris yang memiliki surat tanda terdaftar atau ber-STTD wajib membayar biaya tahunan, dengan batas waktu pembayaran terakhir 31 Desember setiap tahunnya. Bagi notaris yang tidak membayar kewajibannya atau membayar tagihan tahunan terebut akan mendapatkan surat teguran. Sehingga tidak ada perbedaan terhadap notaris yang berkegiatan membuat akta di pasar modal maupun tidak berkegiatan di pasar modal, selama memiliki STTD maka notaris tersebut 
harus membayar biaya tahunan terakhir pada 31 Desember setiap tahunnya.

Notaris ber-STTD yang tidak berkegiatan di pasar modal tetap harus membayar biaya tahunan. Jika notaris ber-STTD namun tidak berkegiatan atau tidak membuat akta di pasar modal dan tidak melakukan pembayaran atau tidak membayar pungutan OJK, maka OJK akan memberikan surat teguran, kewajiban membayar tagihan pungutan tersebut, paling lambat 30 (tiga puluh) hari sejak tanggal teguran pertama. Surat teguran ini berlaku untuk semua notaris yang ber-STTD atau memiliki surat terdaftar tanpa terkecuali. OJK dalam hal ini tidak membedakan biaya tahunan yang dikenakan, dalam hal ini apakah notaris berSTTD tersebut berkegiatan maupun tidak berkegiatan. Selama notaris memiliki STTD maka OJK mewajibkan untuk membayar dan akan mengirimkan surat teguran jika telat untuk membayar.

Tidak berhenti pada surat teguran, OJK melakukan pengenaan sanksi administrasi berupa denda sebesar 2\% (dua persen) per bulan dari kewajiban pembayaran pungutan yang wajib dibayar karena keterlambatannya melakukan pembayaran. Denda maksimal paling banyak adalah 48\% (empat puluh delapan persen) dari pungutan yang wajib dibayar.

Seluruh notaris yang ber-STTD meskipun tidak berkegiatan di Pasar Modal mendapat surat teguran pertama juga mendapatkan denda $2 \%$ (dua persen) setiap bulannya dari kewajiban pembayaran Rp. 5.000.000,- atau Rp. 100.000,- (seratus ribu rupiah) setiap bulannya jika tidak membayar. Dan denda maksimal Rp. 2.400.000,- (dua juta empat ratus ribu rupiah) setiap tahunnya jika tidak membayar pungutan OJK.

Dalam hal notaris ber-STTD tidak melunasi kewajibannya dalam jangka waktu 1 (satu) tahun sejak berakhirnya jangka waktu pembayaran pungutan, dan telah menerima surat teguran sebanyak 2 kali, maka OJK menetapkannya sebagai piutang macet. OJK akan menyerahkan penagihan atas pungutan tersebut beserta dendanya kepada panitia urusan piutang negara. Dan pembayaran selanjutnya akan dilakukan oleh panitia urusan piutang negara. OJK memberikan kriteria bagi notaris yang berSTTD untuk mendapat keringanan dalam pembayaran, jika notaris tersebut telah dinyatakan pailit oleh pengadilan.

Pengecualian pembayaran pungutan tahunan tidak berlaku karena notaris yang memiliki surat terdaftar atau ber-STTD namun tidak berkegiatan di pasar modal karena tidak pernah membuat akta terkait pasar modal. Sedangkan putusan pailit bagi seorang notaris merupakan sesuatu hal yang jarang terjadi bahkan tidak pernah terjadi selama ini. Sehingga kemungkinan sangat kecil untuk seorang notaris mendapat pengecualian dalam pembayaran pungutan tahunan oleh OJK. Lahirnya sanksi dalam hal ini adalah sanksi yang timbul, yaitu teguran sanksi administrasi berupa denda. Teguran yang disampaikan kepada notaris ber-STTD tidak berkegiatan di pasar modal dan tidak membayar pungutan dilakukan sebanyak dua kali teguran. Sedangkan sanksi administrasi yang timbul adalah berupa denda $2 \%$ (dua persen) setiap bulannya atau $\mathrm{Rp} 100.000$,-(seratus ribu rupiah), dengan denda maksimal 48\% (empat puluh delapan persen) atau $\mathrm{Rp}$ 2.400.000,- (dua juta empat ratus ribu rupiah). Terhitung setelah satu tahun sejak batas akhir pembayaran pungutan, notari ber-STTD yang tidak berkegiatan di pasar modal dan tidak membayar pungutan maupun dendanya, maka oleh OJK dilimpahkan kepada panitia uruan piutang negara dan menjadi piutang negara.

Panitia Urusan Piutang Negara dapat melakukan penagihan sekaligus dengan Surat Paksa dalam hal pernyataan bersama telah dibuat, tetapi penanggung hutang tidak mentaati kesepakatan yang tercantum dalam pernyataan bersama, dan atas hal itu KP2LN telah melakukan peringatan 
secara tertulis; atau pernyataan bersama tidak dapat dibuat, dan PUPN Cabang telah menerbitkan Penetapan Jumlah Piutang Negara (PJPN).

Dalam ketentuan yang pertama bahwa memang telah terjadi perjanjian antara yang berhutang dengan panitian urusan piutang negara untuk dibuat perjanjian. Namun notaris yang tidak membayar pungutan OJK masuk dalam katagori kedua, bahwa tidak ada kesepakatan dengan notaris. Sehingga panitia urusan piutan negara langsung menerbitkan penetapan jumlah piutang negara dengan surat paksa untuk melakukan pembayaran pungutan dan denda pungutan.

Ketentuan tentang Surat Paksa terdapat pada Pasal 11 Undang-Undang Panitia Urusan Piutang Negara. Secara khusus,

\section{SIMPULAN}

1. Otoritas Jasa Keuangan (OJK) mendapat kewenangan atribusi sesuai dengan amanat Undang-Undang Bank Indonesia dan Undang-Undang Otoritas Jasa Keuangan, yaitu untuk melaksanakan tugas pengawasan dan pengaturan dalam sektor jasa keuangan. Sumber pembiayaannya berasal dari APBN dan pungutan yang dilakukan OJK, termasuk pungutan terhadap notaris

2. Implikasi hukum yang timbul dari

\section{DAFTAR RUJUKAN}

Ali, Ahmad. 2008. Menguat Tabir Hukum. Bogor. Ghalia Indonesia

Balfas, Hamud M. 2012. Hukum Pasar Modal Indonesia. Jakarta. PT. Tatanusa

Hadjon, Philipus M. \& Djatmiati, Tatiek Sri. 2011. Argumentasi Hukum. Yogyakarta. UGM Press

Naskah Akademik Rancangan UndangUndang Otoritas Jasa Keuangan

Peraturan Pemerintah Nomor 11 Tahun 2014 tentang Pungutan Otoritas Jasa Keuangan. Lembaran Negara Republik Indonesia Tahun 2014 Nomor 33. di dalam ketentuan pasal tersebut tidak terdapat pengertian tentang Surat Paksa. Namun dari uraian Pasal 11 tersebut di atas dapat ditarik suatu pengertian bahwa Surat Paksa adalah surat perintah yang berkepala "Demi Keadilan Berdsarkan Ketuhanan Yang Maha Esa" yang dikeluarkan oleh Ketua Panitia Urusan Piutang Negara kepada Penanggung Hutang (dalam hal ini notaris yang tidak membayar pungutan) untuk membayar secara sekaligus seluruh hutangnya kepada negara berdasarkan Undang-Undang Panitia Urusan Piutang Negara. Surat Paksa juga mempunyai kekuatan yang sama seperti grosse akta dari putusan hakim dalam perkara perdata, yang tidak dapat dimintakan banding lagi pada hakim atasan.

Peraturan Pemerintah Nomor 11 Tahun 2014 tentang Pungutan Otoritas Jasa Keuangan bagi notaris yang memiliki STTD namun tidak berkegiatan di pasar modal adalah menjadi piutang negara. Pembayaran akan dilakukan oleh panitia urusan piutang negara, dengan surat paksa yang mempunyai kekuatan hukum yang sama dengan grosse akta.

Tambahan Lembaran Negara Republik Indonesia Nomor 5504

Peraturan Otortas Jasa Keuangan Nomor:3/ POJK.02/2014 tentang Tata Cara Pelaksanaan Pungutan Oleh Otoritas Jasa Keuangan. Lembaran Negara Nomor 66 Tahun 2014. Tambahan Lembaran Negara Nomor 5521

Pramarta, Billy Adhi. Safa'at, Rachmad. \& Djatmika, Prija. 2019. Pertanggungjawaban Pidana Notaris dan Para Pihak yang Memalsukan Surat Keterangan Obyek Pewaris. JIPPK, 
Implikasi yuridis peraturan pemerintah ...161

Volume 3, Nomor 1, Halaman 22-29, ISSN: 2528-0767 (p) dan 2527-8495

(e). Sumber: http://journal2.um.ac. id/index.php/jppk

Putusan Mahkamah Agung Nomor:68/P/ HUM/201

Risalah Persidang Rancangan UndangUndang Otoritas Jasa Keuangan yang dilakukan di Komisi XI DPR dengan agenda penjelasan RUU OJK oleh pemerintah dalam hal ini Menteri Keuangan dan Menteri Hukum dan HAM serta mendengarkan pendapat dari fraksi-fraksi di DPR.

Risalah Persidangan Pembahasan UndangUndang Bank Indonesia di Dewan Perwakilan Rakyat. Sidang pembahasan Komisi XI DPR, BI dengan pemerintah Undang-Undang Nomor 8 Tahun 1995 tentang Pasar Modal. Lembaran Negara Republik Indonesia Tahun 1995 Nomor 64. Tambahan Lembaran negara Republik Indonesia 3608.
Undang-Undang Nomor 21 Tahun 2011 Tentang Otoritas Jasa Keuangan. Lembaran Negara Republik Indonesia Tahun 2011 Nomor 111. Tambahan Lembaran Negara Republik Indonesia Tahun 2011 Nomor 5253

Undang-Undang Nomor 49 Prp. Tahun 1960 tentang Panitia Urusan Piutang Negara. Lembaran Negara Republik Indonesia Tahun 1960 Nomor 156. Tambahan Lembaran Negara Republik Indonesia Nomor 2104

Yoga, I Gusti Kade Prabawa Maha. Kusumadara, Afifah. \& Kawuryan, Endang Sri. 2018. Kewenangan Notaris Dalam Pembuatan Surat Keterangan Waris Untuk Warga Negara Indonesia. JIPPK, Volume 3, Nomor 2, Halaman 132-143. ISSN: 2528-0767 (p) dan 2527-8495 (e). Sumber: http://journal2.um.ac.id/ index.php/jppk 